\title{
Hypogeal scale insects (Hemiptera: Coccomorpha) of the coffee agro-system in Chiapas state, Mexico, with description of a new species of Williamsrhizoecus Kozár and Konczné Benedicty (Rhizoecidae)
}

\author{
Alejandro Caballero ${ }^{* *}$ and Andrea Amalia Ramos-Portilla ${ }^{2}$
}

\begin{abstract}
Background: The goal of this research is to provide new information about the hypogeal scale insects associated with coffee crops in Mexico. This plant is associated with many insects, among others, the scale insects. This group of insects are potential pests in coffee crops because they are exclusive phytophagous. Until now, there are more than 500 scale insects species recorded in Mexico, 19 of them in Chiapas State. The rhizosphere of the coffee plants contains high diversity of scale insects (Hemiptera: Coccomorpha) that have not been studied until now. Samples were collected from coffee and undetermined species of Poaceae roots, in Chiapas State, Mexico, in November 2014, and mature female specimens were identified to species level.

Results: Specimens of Dysmicoccus texensis (Pseudococcidae), Geococcus coffeae, Pseudorhizoecus proximus, Rhizoecus colombiensis, Rhizoecus neostangei and Ripersiella campestris, (Rhizoecidae) and Insignorthezia insignis and Mixorthezia minima (Ortheziidae) were identified. Pseudorhizoecus proximus, R. campestris and M. minima are recorded for the first time from Mexico. In addition, a new species, Williamsrhizoecus coffeae Caballero and Ramos sp. nov., is described.

Conclusions: New information about phytophagous insects are presented to Mexico and the world. Nine species of infraorder Coccomorpha are recorded for Mexico, two of them are new registers, and one species new to science is described.
\end{abstract}

Keywords: Coffea, Coccoidea, Orthezioidea, Neotropic region, Chiapas state, New species

\section{Background}

Mexico is the sixth largest producer of coffee (Coffea arabica L., Rubiaceae) in the world, after Brazil, Vietnam, Indonesia, Colombia, and India (International Coffee Organization, 2016). The crop is produced in 12 states of Mexican Republic, on 670,000 ha, in the south-central part of the country (Colima, Chiapas, Guerrero, Hidalgo, Jalisco, Nayarit, Oaxaca, Puebla, Querétaro, San Luis Potosí, Tabasco, and Veracruz States) (Flores, 2015). These states are grouped in four regions, where the Soconusco bioregion, integrated by a big

\footnotetext{
* Correspondence: lacaballeror@unal.edu.co

${ }^{1}$ Facultad de Ciencias Agraria, Museo Entomológico UNAB, Universidad Nacional de Colombia, Carrera 30 № 45-03, Edificio 500, Bogotá, DC, Colombia

Full list of author information is available at the end of the article
}

proportion of the Chiapas state, specializes in the production of organic coffee, in high demand for north American and European markets (Flores, 2015). This crop hosts 181 species of scale insects, several of which are considered as pests by coffee-producing countries like Brazil, Colombia, Zimbabwe, Kenya, and India (Culik, Martins, \& Gullan, 2006; García Morales, Denno, Miller, Miller, Ben-Dov, \& Hardy, 2016; Granara de Willink, Pirovani, \& Ferreira, 2010; Watson \& Cox, 1990).

Mexico has 594 Coccomorpha species recorded from various host plants, both on aerial and subterraneous parts (García Morales et al., 2016). The state of Chiapas has 19 species recorded belonging to 6 families, namely Asterolecanium epidendri (Bouché) and Palmaspis truncata (Russell) 
(Asterolecaniidae); Chionaspis caudata Vea, Gwiazdowski and Normark, Crenulaspidiotus maurellae (Laing), Melanaspis coccolobae Ferris, Melanaspis elaeagni McKenzie, Melanaspis pinicola Deitz and Davidson, and Melanaspis tenax McKenzie (Diaspididae); Mahunkacoccus mexicoensis Kozár and Konczné Benedicty (Carayonemidae); Coccus viridis (Green), Milviscutulus mangiferae (Green), and Protopulvinaria pyriformis (Cockerell) (Coccidae); Dactylopius opuntiae (Cockerell) (Dactylopiidae); Crypticerya rosae (Riley and Howard), Echinicerya anomala Morrison, Icerya purchasi Maskell, Laurencella marikana Foldi, and Llaveia axin axin (Llave) (Monophlebidae); and Newsteadia tristani (Silvestri) (Ortheziidae) (Deitz \& Davidson, 1986; Foldi, 1995; Hodgson \& Foldi, 2006; Kozár, 2004; Kozár \& Konczné Benedicty, 2007; D R Miller, 1996; D R Miller \& Davidson, 1981, 2005; Morrison, 1952; Unruh \& Gullan, 2008; Vea, Gwiazdowski, \& Normark, 2012; Williams \& Granara de Willink, 1992). Among these species, only Coccus viridis has been recorded on Coffeae spp. (Rubiaceae) (García Morales et al., 2016; D R Miller, 1996).

Records of the hypogeal scale insects fauna associated with coffee crops in Mexico are rather poor, especially in Chiapas state; so the objective of this research is to contribute to the knowledge of the Coccomorpha of Mexico, with emphasis on the hypogean scale insects on coffee crops. We present six records from Chiapas state: one for Pseudococcidae, one of Ortheziidae, and four of Rhizoecidae; some of them are new country and host records. We describe a new hypogeal scale insect species of Williamsrhizoecus Kozár \& Konczné Benedicty, 2007 feeding on the roots of Coffea arabica.

\section{Methods}

Scale insect specimens were collected from the roots of Coffea arabica plants in different municipalities of Chiapas State, Mexico, during November 2014. They were preserved in $75 \%$ ethanol. Slide-mounted specimens were prepared according to protocol of Sirisena, Watson, Hemachandra and Wijayagunasekara (2013) with modifications, in the laboratory of entomologic museum UNAB (Universidad Nacional Agronomía Bogotá) Universidad Nacional de Colombia (Bogotá, Colombia). Analysis of images and anatomical measurements were done using a Nikon Eclipse E600 phase contrast compound microscope, an Olympus CX31 dissection microscope, a Lumenera Infinity $1-5 \mathrm{C}$ microscope camera, and Image Pro Insigth v 8.0 software.

The insects were identified using the taxonomic keys and descriptions in Green (1933), Hambleton (1946), Williams and Granara de Willink (1992), Kozár (2004), Kozár and Konczné Benedicty (2007), and Granara de Willink (2009). All specimens, included Type material, were deposit in UNAB.
The terminology used in the description follows that of Hambleton (1946), while the taxonomic illustration follows the style of Ferris (1953). The measurement values presented, in order, are mean, standard deviation, measurement of the Holotype [in brackets], and measurement of the paratypes (in parentheses). The standardized measurements of anatomical features (e.g., antennal segments, legs segments, anal ring, and genital chamber) are illustrated in Fig. 1. The measurement of body length spans the distance, in a longitudinal line, from the extreme anterior point of the head (a point in the middle between the antennal bases) to the extreme posterior edge of the anal ring; measurement of body width spans transverse line across the widest point. The antennal segmentation is abridged as $S_{\text {ant }} \mathrm{I}$ to antennal segment 1 , $\mathrm{S}_{\text {ant }} \mathrm{II}$ to antennal segment $2, \mathrm{~S}_{\text {ant }} \mathrm{III}, \ldots, \mathrm{S}_{\text {ant }} \mathrm{VI}$ to antennal segment 6 , and the abdominal segmentation as $S_{\text {abd }} I$ to abdominal segment $1, \mathrm{~S}_{\mathrm{abd}} \mathrm{II}$ abdominal segment 2 , $\mathrm{S}_{\text {abd }} \mathrm{III}, \ldots, \mathrm{S}_{\mathrm{abd}}$ VIII to abdominal segment 8 .

\section{Results and discussion \\ Ortheziidae}

Insignorthezia insignis (Browne) MEXICO. Chiapas, Tapachula, $15^{\circ} 3^{\prime}$ 0.90' 'North, 92 14' 36.60' West, 520 m, 18 Nov 2014, in soil, A. Ramos, one adult female, UNAB 1499.

Comments: Insignorthezia insignis was previously recorded from Mexico by D R Miller (1996); this is the first record of the species from Chiapas state.

Mixorthezia minima Konczné Benedicty and Kozár MEXICO. Chiapas, Tapachula, $15^{\circ} 6^{\prime} 10.70^{\prime \prime}$ North, $92^{\circ}$ 18' 38.90' 'West, 449 m, 14 Nov 2014, ex roots of Coffea arabica (Rubiaceae), A. Ramos, two adult females, UNAB 1862.

Comments: Previously, M. minima has been recorded only from Brazil (Kozár, 2004). This is the first record from another country in the New World and is the first time that a host has been recorded for this species.

\section{Pseudococcidae}

Dysmicoccus texensis (Tinsley) MEXICO. Chiapas, Tapachula, Piedra Redonda, $15^{\circ} 3^{\prime} 50.04^{\prime \prime}$ North, $92^{\circ}$ $19^{\prime} 37.20^{\prime \prime}$ West, 466 m, 14 Nov 2014, ex roots of Coffea arabica (Rubiaceae) associated with Basidiomycota fungi, A. Ramos, six adult females UNAB 1496. Chiapas, Tapachula, $15^{\circ} 6^{\prime} 10.70^{\prime \prime}$ North, $92^{\circ} 18^{\prime} 38.90^{\prime \prime}$ West, 449 m, 14 Nov 2014, ex roots of Coffea arabica (Rubiaceae), A. Ramos, one adult female + two 3rd-instar females UNAB 1496. Chiapas, Cacahoatan, Ahuacatlan, La Alianza Farm, $15^{\circ} 2^{\prime} 16.80^{\prime \prime}$ North, 90 $10^{\prime} 48^{\prime \prime}$ West, 676 m, 18 Nov 2014, ex roots of Coffea arabica (Rubiaceae), A. Ramos, three adult females + three 3rd-instar larvae + five 2nd-instar larvae UNAB 1496. 
Comments: Dysmicoccus texensis was recorded from Mexico on Coffea arabica by Williams and Granara de Willink (1992), but this is the first record from Chiapas state.

\section{Rhizoecidae}

Geococcus coffeae Green MEXICO, Chiapas, Cacahoatan, Ahuacatlan, La Alianza Farm, 15 $2^{\prime}$ 16.80' ' North, $90^{\circ} 10^{\prime} 48^{\prime \prime}$ 'West, 676 m, 18 Nov 2014, ex roots of Coffea arabica (Rubiaceae), A. Ramos, six adult females UNAB 1498. Chiapas, Tapachula, $15^{\circ} 6^{\prime} 10.70^{\prime \prime}$ North, 92 $12^{\prime}$ 38.90' 'West, 449 m, 14 Nov 2014, ex roots of Coffea arabica (Rubiaceae), A. Ramos, two adult females UNAB 1498. Chiapas, Tapachula, Edubijes Farm, $15^{\circ} 6^{\prime}$ 57.10' ' North, 92 $18^{\prime} 11^{\prime \prime}$ ' West, 519 m, 18 Nov 2014, ex roots of Coffea arabica (Rubiaceae), A. Ramos, two adult females UNAB 1498. Chiapas, Tapachula, Hamburgo Farm, 1218 m, 19 Nov 2014, ex roots of Coffea arabica (Rubiaceae) and undetermined species of Poaceae, A. Ramos, two adult females UNAB 1498. Chiapas, Tapachula, La Chiripa Farm, 15 9' 25' ' North, 92 $19^{\prime}$ $4.40^{\prime \prime}$ West, 871 m, 19 Nov 2014, ex roots of Coffea arabica (Rubiaceae), A. Ramos, five adult females UNAB 1498. Chiapas, Tapachula, La Chiripa Farm, $15^{\circ} 10^{\prime}$ 26.20' ' North, 92 4' 4.46' ' West, 871 m, 19 Nov 2014, ex roots of undetermined species of Poaceae, A. Ramos, five adult females UNAB 1498.

Comments: In Mexico, G. coffeae has been recorded previously only from Mexico state (Ben-Dov, 1994; Kozár \& Konczné Benedicty, 2007; Williams \& Granara de Willink, 1992). This is the first record from Chiapas state.

Pseudorhizoecus proximus green MEXICO. Chiapas, Tapachula, Edubijes Farm, 156' 57.10' ' North, 92 $18^{\circ}$ $11^{\prime \prime}$ West, 519 m, 18 Nov 2014, ex roots of Coffea arabica (Rubiaceae), A. Ramos, seven adult females UNAB 1875.

Comments: Pseudorhizoecus proximus is recorded from Mexico for the first time. The species was reported previously on C. liberica from Surinam, Coffea arabica from Colombia, and Coffea sp. from Ecuador and Guatemala by Hambleton (1977), Williams and Granara de Willink (1992), and Ben-Dov (1994).

Rhizoecus colombiensis Ramos and Caballero MEXICO. Chiapas, Cacahoatan, Ahuacatlan, La Alianza farm, $15^{\circ} 2^{\prime}$ $1680^{\prime \prime}$ 'North, 90 $10^{\prime} 48^{\prime \prime}$ West, 676 m, in soil, $18 \mathrm{Nov}$ 2014, A. Ramos, two adult females UNAB 678. Chiapas, Tapachula, $15^{\circ} 3^{\prime} 0.90^{\prime \prime}$ North, 92 $14^{\prime} 36.60^{\prime \prime}$ West, $520 \mathrm{~m}$, in soil, $18 \mathrm{Nov}$ 2014, A. Ramos, thirteen adult females UNAB 678.

Comments: Rhizoecus colombiensis has been found feeding on coffee roots from Mexico previously by Ramos-Portilla and Caballero (2016).
Rhizoecus neostangei Miller and McKenzie MEXICO. Chiapas, Tapachula, La Chiripa Farm, $15^{\circ} 10^{\prime} 26.20^{\prime \prime}$ North, 92 $19^{\prime} 4.46^{\prime \prime}$ West, $871 \mathrm{~m}$, ex roots of undetermined species of Poaceae. 19 Nov 2014, A. Ramos, one adult female UNAB 1508.

Comments: Rhizoecus neostangei was recorded in Mexico only associated with Rhus sp. (Anacardiaceae) by D R Miller and McKenzie (1971), Williams and Granara de Willink (1992), and Ben-Dov (1994). This is the first record of $R$. neostangei associated with any species of Poaceae.

Ripersiella campestris Hambleton MEXICO. Chiapas, Cacahoatan, Ahuacatlan, La Alianza Farm, 15 $2^{\prime} 1680^{\prime \prime}$ North, 90'10' 48' 'West, 676 m, 18 Nov 2014, ex roots of Coffea arabica (Rubiaceae), A. Ramos, two adult females UNAB 1497. Chiapas, Tapachula, $15^{\circ} 6^{\prime} 10.70^{\prime \prime}$ North, 92 $18^{\prime}$ 38.90'" West, 449 m, 14 Nov 2014, ex roots of Coffea arabica (Rubiaceae), A. Ramos, one adult female UNAB 1497. Chiapas, Tapachula, Edubijes Farm, $15^{\circ} 6^{\prime} 57.10^{\prime \prime}$ North, 92 $18^{\prime} 11^{\prime \prime}$ 'West, 519 m, 18 Nov 2014, ex roots of Coffea arabica (Rubiaceae), A. Ramos, three adults female UNAB 1497. Chiapas, Tapachula, La Chiripa Farm, $15^{\circ} 10^{\prime} 26.20^{\prime \prime}$ North, 92 $19^{\prime} 4.46^{\prime \prime}$ West, $871 \mathrm{~m}$, ex roots of undetermined species of Poaceae, 19 Nov 2014, A. Ramos, four adults female UNAB 1497.

Comments: This is the first record of $R$. campestris from Mexico and association with Poaceae species. It has been recorded previously on $C$. arabica and undetermined species of Asteraceae (Ben-Dov, 1994; Hambleton, 1976; Williams \& Granara de Willink, 1992).

Williamsrhizoecus coffeae Caballero and Ramos sp. nov. Type material. Holotype: adult female. MEXICO. Chiapas, Tapachula, Fca. Hamburgo, 1218 m, 19 nov 2014, ex roots of Coffea arabica (Rubiaceae), A. Ramos, UNAB 4642. Paratypes: eight adults females, same locality and data as holotype; seven adults females-same locality and date as holotype, ex roots of species undeterminated of Poaceae, A. Ramos, UNAB 4642.

Other material: COLOMBIA, Antioquia, Venecia, Vda. Palenque, Fca. La Ilusión, $5^{\circ} 27^{\prime} 00^{\prime \prime}$ North, 75 $73^{\prime} 00^{\prime \prime}$ West, 1350 m, 22 Oct 2015, ex roots of Coffea arabica (Rubiaceae), UNAB 4639 (Figs. 1 and 2).

\section{Description}

Body elongate oval, $732 \pm 302$ [656] (674-870) $\mu \mathrm{m}$ long, $551 \pm 164$ [408] (418-674) $\mu \mathrm{m}$ wide.

\section{Dorsum}

Ostioles absent. Anal ring oval or circular (Figs. 1a and 2a), transverse diameter $51 \pm 3$ [55] (48-57); ring containing 8-16 [12] cells, each without spicules, and bearing 6-17 [16] flagellate setae, each $27 \pm 6(10-42) \mu \mathrm{m}$ 

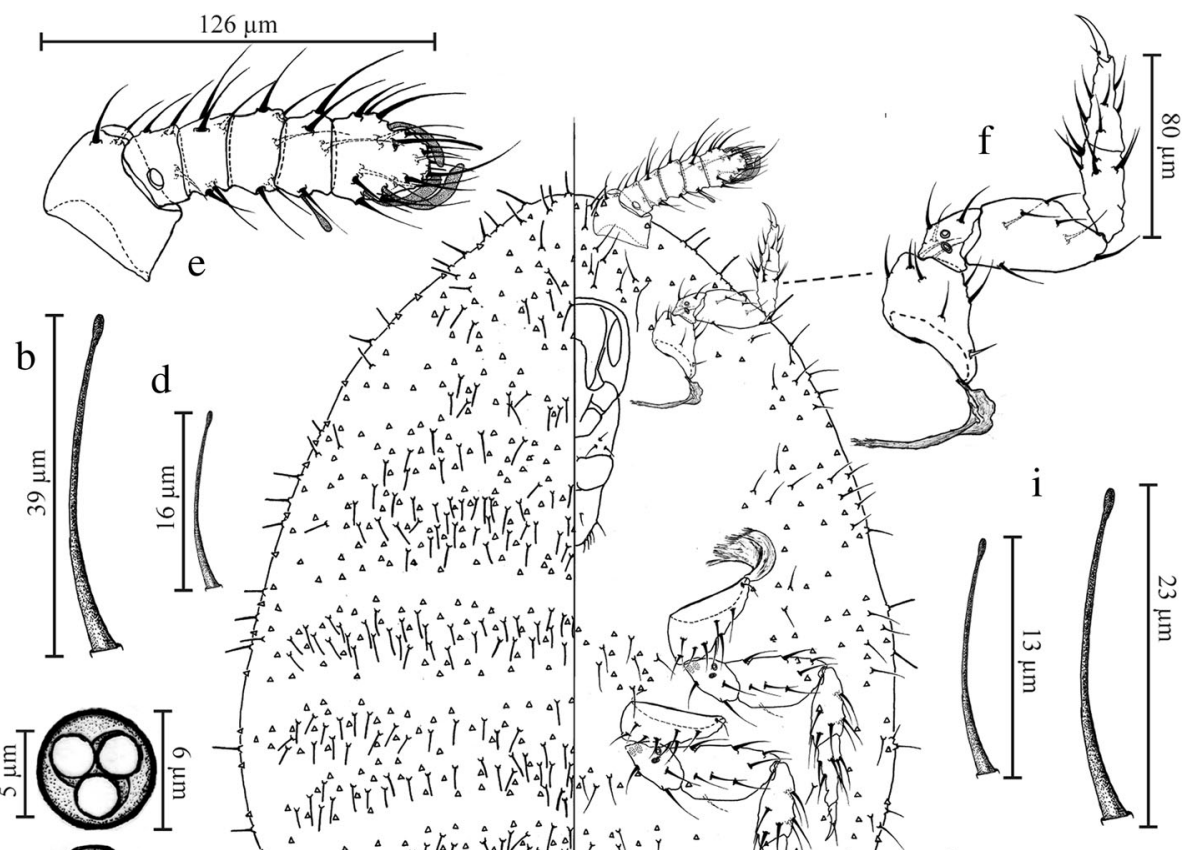

然 


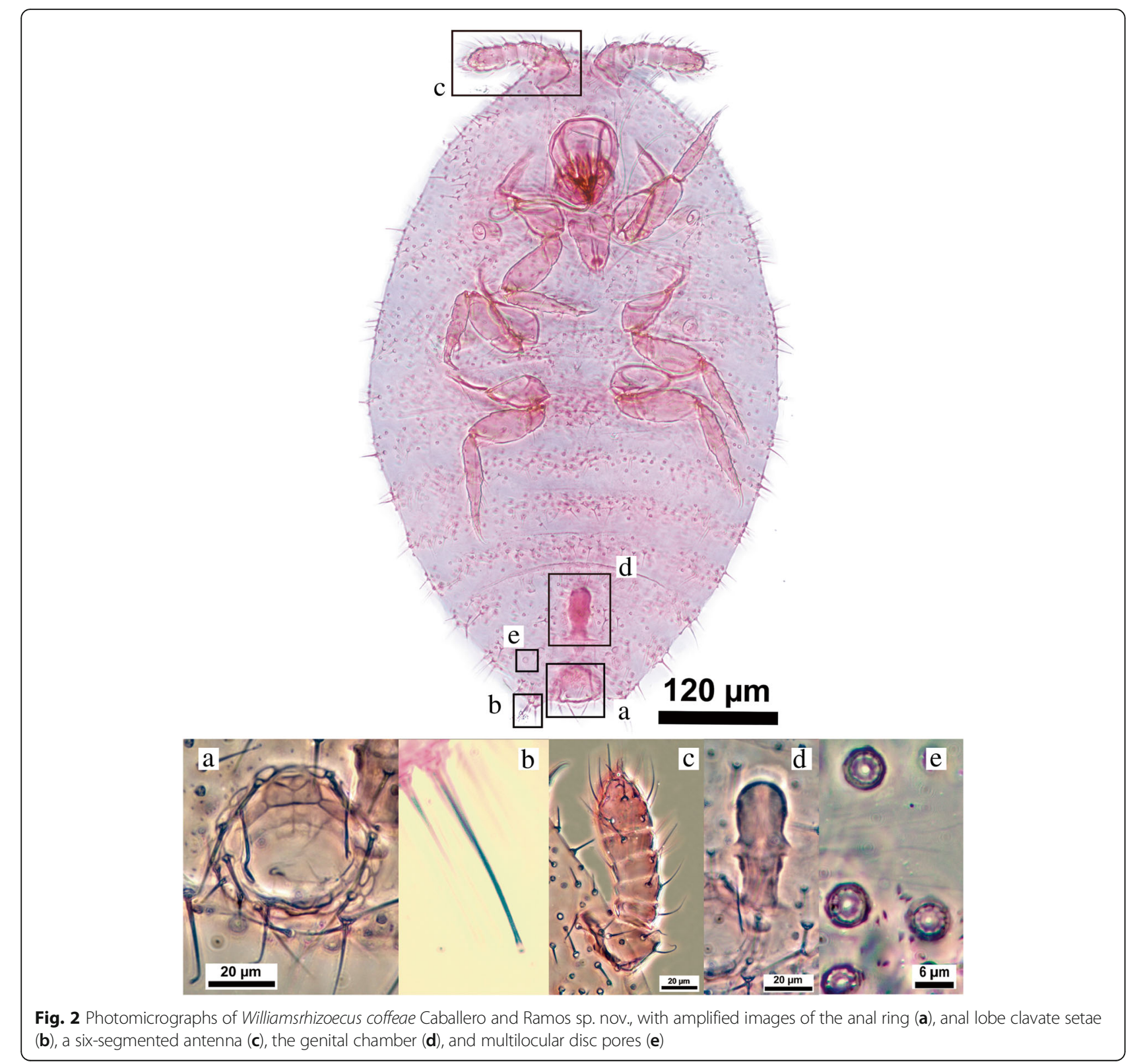

(30-40) $\mu \mathrm{m}$ wide; tibia + tarsus $77 \pm 20(71-83) \mu \mathrm{m}$ long, tibia $18 \pm 5(20-15) \mu \mathrm{m}$ wide; claw $22 \pm 6(20-24) \mu \mathrm{m}$ long; ratio of trochanter + femur length: tibia + tarsus length 1.1 \pm 0.3 (1-1.2); ratio of trochanter + femur length: femur width $2.4 \pm 0.9$ (2.1-2.8), ratio of tibio + tarsus length: tibia width $4.4 \pm 1.2$ (3.8-5.6). Mid leg $178 \pm 6(167-187) \mu \mathrm{m}$ long; trochanter + femur $81 \pm 3(76-85) \mu \mathrm{m}$ long; femur width $31 \pm 3(26-38) \mu \mathrm{m}$; tibia + tarsus $76 \pm 3(71-82) \mu \mathrm{m}$ long, tibia $17 \pm 1(16-21) \mu \mathrm{m}$ long; claw $22 \pm 1(19-24) \mu \mathrm{m}$ long; ratio of trochanter + femur length: tibia + tarsus length $1.1(1-1.1)$, ratio of trochanter + femur length: femur width $2.6 \pm 0.3(2.2-3.3)$, ratio of tibia + tarsus length: tibia width $4.3 \pm 0.3$ (3.8-4.9). Hind leg $202 \pm 8$ (185-214) $\mu \mathrm{m}$ long; trochanter + femur length $86 \pm 4$ (77-92) $\mu \mathrm{m}$; femur width $34 \pm 2(32-40) \mu \mathrm{m}$; tibia + tarsus length $93 \pm 4$ (86100) $\mu \mathrm{m}$, tibia width $8 \pm 1(17-20) \mu \mathrm{m}$; claw $23 \pm 2(19-25)$ $\mu \mathrm{m}$ long; ratio of trochanter + femur length: tibia + tarsus length 0.9 (0.9-1), ratio of trochanter + femur length: femur width $2.5 \pm 0.2(2.2-2.9)$, ratio of tibia + tarsus length: tibia width $5.1 \pm 0.4$ (4.6-6). Chetotaxy: Fore coxa with 7-9 flagellate setae; fore tibiae each with preapical internal setae flagellate; mid- and hind tibiae each with 1 preapical internal flagellate setae and the other spur-like. Fore- and hind tarsi with 1 marginal internal spur; mid tarsus with 2 marginal internal spurs. Claw digitules short, half or less than claw long, setose.

Circuli absent. Genital chamber globose, tapering progressively toward the posterior third forming a neck, 
which them thickens towards the base (Figs. $1 \mathrm{~g}$ and 2d), $55 \pm 4$ [53] (47-61) $\mu \mathrm{m}$ long. Spiracles situated in proand mesothorax: anterior peritremes 18,1-18.5 $\mu \mathrm{m}$ (17.7-19) long; posterior peritremes 18.3-18.7 $\mu \mathrm{m}$ (17.4-18.7) long. Multilocular disc pores present (Fig. $1 \mathrm{~h})$, each pore $7 \pm 0.5(6-8) \mu \mathrm{m}$ in diameter, with $7-10$ loculi; distribution 0 on head, $0-1$ [1] on prothorax, 0-2 [0] on mesothorax, 0-1 [0] on metathorax, absent from $\mathrm{S}_{\text {abd }} \mathrm{I}$ to $\mathrm{S}_{\text {abd }} \mathrm{V}, 0-3$ [1] on $\mathrm{S}_{\text {abd }}$ VI, 0-9 [1] on $\mathrm{S}_{\text {abd }}$ VII, 917 [12] on $S_{a b d}$ VIII. Trilocular pores evenly scattered, each subtriangular, with loculi protruding from cuticular surface, diameter 3-4 $\mu \mathrm{m}$. Tritubular cerores absent. Body setae clavate, situated in submarginal and marginal areas of head and thorax, and marginal areas of $\mathrm{S}_{\mathrm{abd}} \mathrm{I}$ to $\mathrm{S}_{\mathrm{abd}}$ VII (Fig. 1i), each seta $19 \pm 4,5(10-27) \mu \mathrm{m}$ long; flagellate setae present in mesial and submesial area, each 9-28 $\mu \mathrm{m}$ long; longitudinal body area, between submeson and submargin, bare.

Diagnosis. Antenna 6-segmented; clavate setae present on entire dorsal surface and restricted to submarginal and marginal areas of venter, absent from antennae; multilocular disc pores present on venter and circulus absent.

Discussion. The genus Williamsrhizoecus Kozár and Konczné Benedicty is composed of two species: Williamsrhizoecus epicoccus (Williams) and W. baskyi Kozár and Konczné Benedicty. The diagnostic character of this genus is the presence of clavate setae (Kozár \& Konczné Benedicty, 2007). Williamsrhizoecus coffeae differs of other two species because it has multilocular disc pores and lacks a circulus and any tritubular cerores in venter; in addition, the distribution of the clavate setae is different. In Williamsrhizoecus epicoccus, this type of seta is present only on the anal ring, while the body setae are flagellates; in W. baskyi, clavate setae are present on both dorsal and ventral surfaces, and the antennae and legs, but the setae on the anal ring are flagellate.

Etymology. The species epithet is derived from the host plant genus Coffea, on which the specimens were found.

Identification key of Williamsrhizoecus species of the World based on mounted adult females.

1. Multilocular disc pores presents; circuli absent. Williamsrhizoecus coffeae

- Multilocular disc pores absent; at least one circulus present. .2

2. One circulus present; anal ring with clavate setae; body surfaces with flagellate setae.....

\section{Williamsrhizoecus epicoccus}

- Two circulus presents; anal ring with flagellate setae; body surfaces with calvate

setae.

\section{Williamsrhizoecus baskyi}

\section{Conclusion}

The knowledge of Coccomorpha in Chiapas state (Mexico) has been improved, as has the knowledge of the host range of some species of this insect group. This research records nine species of Coccomorpha found on the roots of Coffea arabica and undetermined species of Poaceae. Mixorthezia minima, Ripersiella campestris and Pseudorhizoecus proximus are new country records for Mexico. For the first time, Mixorthezia minima is recorded feeding on C. arabica, while Rhizoecus neostangei and $R$. campestris are recorded feeding on member of the family Poaceae. Finally, a new species found on the roots of coffee, Williamsrhizoecus coffeae Caballero and Ramos sp. nov., is described; its distribution includes Colombia and Mexico. The identity of some species present on the roots of coffee crops has been clarified, ready to be incorporated in the future programs of integrated management of these pests.

\section{Abbreviations \\ Sabdl: Abdominal segment 1; $S_{a b d}$ ll: Abdominal segment 2; $S_{a b d}$ lll: Abdominal segment 3; $\mathrm{S}_{\mathrm{abd}} \mathrm{IV}$ : Abdominal segment 4; $\mathrm{S}_{\mathrm{abd}} \mathrm{V}$ : Abdominal segment 5; $\mathrm{S}_{\mathrm{abd}} \mathrm{Vl}$ : Abdominal segment 6; $\mathrm{S}_{\mathrm{abd}} \mathrm{VII}$ : Abdominal segment 7; \\ $\mathrm{S}_{\text {abd }} \mathrm{VIII}$ : Abdominal segment $8 ; \mathrm{S}_{\text {ant }}$ : Antennal segment $1 ; \mathrm{S}_{\text {ant }}$ ll: Antennal segment 2; $S_{\text {ant }}$ III: Antennal segment 3; $S_{\text {ant }} \mathrm{IV}$ : Antennal segment 4; \\ $S_{a n t} V l$ : Antennal segment 5; UNAB: Universidad Nacional Agronomía Bogotá}

\section{Acknowledgements}

We thanks to Dr. Juan Barrera and Giber González from "El Colegio de la Frontera Sur" (ECOSUR) in Chiapas, Mexico for logistical support to obtain the samples; entomological museum UNAB for the equipment to identify and preserve the biological material; also special thanks to Dr. Takumasa Kondo for check identity of Insignorthezia insignis specimen, Dr. Gillian W. Watson and Dr. Vitor Pacheco da Silva for corrections and suggestions, and to the anonymous reviewers of this manuscript.

\section{Funding}

This study was funded from the Faculty of Agricultural Science of Universidad Nacional de Colombia (Bogotá D.C., Colombia).

\section{Availability of data and materials}

The material type generated and analyzed during the current study are deposited and available in the Coleción Taxonomica Central of entomological museum "Universidad Nacional Agronomia Bogota"—UNAB, from the Faculty of Agricultural Science of Universidad Nacional de Colombia (Bogotá D.C., Colombia).

\section{Authors' contributions}

AC and AR participated equally in the collecting, preparation, and identification of specimens. All authors conceived of the study, read, and approved the final manuscript.

\section{Ethics approval and consent to participate}

All applicable international, national, and/or institutional guidelines for the care and use of animal were followed.

Consent for publication

Not applicable.

\section{Competing interests}

The authors declare that they have no competing interests.

\section{Publisher's Note}

Springer Nature remains neutral with regard to jurisdictional claims in published maps and institutional affiliations. 


\section{Author details}

'Facultad de Ciencias Agraria, Museo Entomológico UNAB, Universidad Nacional de Colombia, Carrera 30 № 45-03, Edificio 500, Bogotá, DC, Colombia. ${ }^{2}$ Dirección Técnica de Sanidad Vegetal, Instituto Colombiano Agropecuario (ICA), Carrera 41 № 17-81, Bogotá, DC, Colombia.

Received: 23 July 2018 Accepted: 9 October 2018

Published online: 01 November 2018

\section{References}

Ben-Dov, Y. (1994). A systematic catalogue of the mealybugs of the world (Insecta, Homoptera, Coccoidea, Pseudococcidae and Putoidae): With data on geographical distribution, host plants, biology, and economic importance. UK: Intercept Limited Andover. Retrieved from https://books.google.com.co/ books?id=UFN3QgAACAAJ

Culik, M. P., Martins, D. d. S., \& Gullan, P. J. (2006). First records of two mealybug species in Brazil and new potential pests of papaya and coffee. Journal of Insect Science, 23, 1-6 https://doi.org/10.1673/2006_06_23.1green.

Deitz, L. L., \& Davidson, J. A. (1986). Synopsis of the armored scale genus Melanaspis in North America (Homoptera: Diaspididae). North Carolina State University Technical Bulletin, 279, 1-91.

Ferris, G. F. (1953). Atlas of the scale insects of North America. The Pseudococcidae (part II) (Vol. VI). California: Stanford University Press.

Flores, F. (2015). La producción de café en México: Ventana de oportunidad para el sector agrícola de Chiapas. Espacio 1+D, Innovación Más Desarrollo, 4(7), 174-194.

Foldi, I. (1995). Margarodidae du Mexique (Hemiptera: Coccoidea). Annales de La Société Entomologique de France, 31(2), 165-178.

García Morales, M., Denno, B., Miller, D. R., Miller, G. L., Ben-Dov, Y., \& Hardy, N. B. (2016). ScaleNet: A literature-based model of scale insect biology and systematics. Database, 2016. https://doi.org/10.1093/database/bav118 [accessed 05 July 2018]

Granara de Willink, M. C. (2009). Dysmicoccus de la Región Neotropical (Hemiptera: Pseudococcidae). Revista de la Sociedad Entomológica Argentina, 68(1-2), 11-95.

Granara de Willink, M. C., Pirovani, V. D., \& Ferreira, P. S. (2010). Las especies de Coccus que afectan Coffea arabica en Brasil (Coccoidea: Coccidae) y redescripción de dos especies. Neotropical Entomology, 39(3), 391-399.

Green, E. E. (1933). Notes on some Coccidae from Surinam, Dutch Guiana, with descriptions of new species. Stylops, 2(3), 49-58 https://doi.org/10.1111/j. 1365-3113.1993.tb00969.x.

Hambleton, E. J. (1946). Studies of hypogeic mealybugs. Revista de Entomologia. Rio de Janeiro, 17(1), 1-77.

Hambleton, E. J. (1976). A revision of the New World mealybugs of the genus Rhizoecus (Homoptera: Pseudococcidae). United States Department of Agriculture Technical Bulletin, 1522, 1-88.

Hambleton, E. J. (1977). Notes on the species of Neorhizoecus Hambleton, a synonym of Rhizoecus Kunckel d'Herculais (Homoptera: Pseudococccidae). Proceedings of the Entomological Society of Washington, 79, 367-376.

Hodgson, C., \& Foldi, I. (2006). A review of the Margarodidae sensu Morrison (Hemiptera: Coccoidea) and some related taxa based on the morphology of adult males II part. Zootaxa, 1263, 1-250.

International Coffee Organization, I. (2016). Coffee market report August 2016 Retrieved from www.ico.org

Kozár, F. (2004). Ortheziidae of the World. Budapest: Plant Protection Institute, Hungarian Academy of Sciences.

Kozár, F., \& Konczné Benedicty, Z. (2007). Rhizoecinae of the World (1st ed.). Budapest: Plant Protection Institute, Hungrian Academy of Sciences.

Miller, D. R. (1996). Checklist of the scale insects (Coccoidea: Homoptera) of Mexico. Proceedings of the Entomological Society of Washington, 98(1), 68-86.

Miller, D. R., \& Davidson, J. A. (1981). A systematic revision of the armored scale genus Crenulaspidiotus MacGillivray Diaspididae, Homoptera. Polskie Pismo Entomologiczne, 514, 531-595.

Miller, D R, \& Davidson, J. A. (2005). Armored scale insect pests of trees and shrubs (Hemiptera: Diaspididae) (1st ed.). Ithaca, United States: Cornell University Press.

Miller, D. R., \& McKenzie, H. L. (1971). Sixth taxonomic study of north American mealybugs, with additional species from South America (Homoptera: Coccoidea: Pseudococcidae). Hilgardia, 40(17), 565-602.
Morrison, H. (1952). Classification of the Ortheziidae: Supplement to classification of scale insects of the subfamily Ortheziinae. Technical Bulletin United States Department of Agriculture Washington, 1052, 1-80.

Ramos-Portilla, A. A., \& Caballero, A. (2016). Rhizoecus colombiensis Ramos \& Caballero, a new species of hypogeal mealybug (Hemiptera: Coccomorpha: Rhizoecidae) and a key to the species of Rhizoecus from Colombia. Zootaxa, 4092(1), 55-68 https://doi.org/10.11646/zootaxa.4092.1.3.

Sirisena, U. G., Watson, G. W., Hemachandra, K. S., \& Wijayagunasekara, H. N. (2013). A modified technique for the preparation of specimens of Sternorrhyncha for taxonomic studies. Tropical Agricultural Research, 24(2), 139-149.

Unruh, C. M., \& Gullan, P. J. (2008). Identification guide to species in the scale insect tribe Iceryini (Coccoidea: Monophlebidae). Zootaxa, 1803, 1-106.

Vea, I. M., Gwiazdowski, R. A., \& Normark, B. B. (2012). Corroborating molecular species discovery: Four new pine-feeding species of Chionaspis (Hemiptera, Diaspididae). ZooKeys, 270(1), 37-58 https://doi.org/10.3897/zookeys.270.2910.

Watson, G. W., \& Cox, J. M. (1990). Identity of the African coffee root mealybug, with descriptions of two new species of Planococcus (Homoptera: Pseudococcidae). Bulletin of Entomological Research, 80(1), 99-105 https://doi. org/10.1017/S0007485300045971.

Williams, D. J., \& Granara de Willink, M. C. (1992). Mealybugs of central and South America (1st ed.). London, UK: CAB International. Retrieved from https:// books.google.com.co/books?id=m9EQAQAAMAAJ

\section{Submit your manuscript to a SpringerOpen ${ }^{\circ}$ journal and benefit from:}

- Convenient online submission

- Rigorous peer review

- Open access: articles freely available online

High visibility within the field

- Retaining the copyright to your article

Submit your next manuscript at $>$ springeropen.com 